\title{
研究短報文
}

\section{IONIC SUBSTITUTIONS IN NATURAL MESOLITES}

\author{
KazUo HaRADa*, KazUSO NAKaO**, and \\ Kozo Nagashima** \\ * Section of Geology, Chichibu Museum of Natural History, Saitama. \\ ** Department of Chemistry, Faculty of Science, Tokyo University of \\ Education, Tokyo.
}

Abstract: Chemical analyses of mesolites confirmed that cationic substitutions took place in wider ranges than those hitherto advocated by Foster (1965) as $\mathrm{Ca}=2.5-1.6, \mathrm{Na}=5.7-1.0(0=30)$. This is further verified by the relatively larger cation-exchange capacity of mesolite determined by Harada, Hara and Nakao (1968).

\section{INTRODUCTION}

In spite of rather abundant occurrences of zeolites as amygdales or veinlets in basic igneous rocks in Japan systematic investigations of these zeolites are still scarce. Recently, occurrences of mesolites and scolecites in the amygdales of basaltic and andesitic rocks in Japan were reported by Harada, Hara and Nakao (1968). The chemical compositions and c.e.c. values were also determined by the authors. At present, zeolites in the amygdales either of basaltic rocks or of palagonite tuffs are considered to be formed under the condition of rather lower-temperature and lower-pressure (Iijima and Harada, 1969).

Iijima and Utada (1966) summarized and discussed the low-temperature and low-pressure formation of low-silica zeolites. Harada (1969) also studied the same subject. However they were not able to extend their discussions to the amygdale-zeolites. If amygdale-zeolites would truly formed under lowtemperature and low-pressure conditions as suggested by Hay (1968, personal comunication), the silica poor zeolites occurring in the amygdales of basaltic rocks and palagonite tuffs may be classified as a low-temperature zeolite group. The group contains phillipsite, gismondine, faujasite, scolecite, mesolite, natrolite, gonnardite, thomsonite, levynite, gmelinite, erionite, chabazite, offretite, analcime, and garronite.

(Manuscript received, December 1, 1968) 
This paper deals with additional descriptions of mesolite occurring in the amygdales or veinlets of Japanese basaltic rocks as well as discussions on possible ionic substitutions of the mineral.

\section{OCGURRENGE}

Mesolite from Moroyose, Hamasaka-machi, Shirosaki-city, HyogoPrefecture, Japan occurring as veinlets with the width up to $1 \mathrm{~cm}$ in altered Tertiary basalt, and mesolites from Taira and Motokohama, Yaizu-city, Shizuoka-Prefecture, Japan occurring as veinlets of 1 to $2 \mathrm{~cm}$ in width in the matrix of pillow lava of Miocene age were studied. All specimens are very thin fibrous aggregates and always associated with calcite, but not with quartz. A remarkable association of stilbite with mesolite from Moroyose is observed.

Carefully hand-picked materials were used for the following studies.

\section{PHYSICAL STUDIES}

Data of specific gravity measured by a pycnometer at $20^{\circ} \mathrm{C}$ and refractive indices measured by the immersion method using $\mathrm{NaD}$ light at $20^{\circ} \mathrm{C}$ are shown in Table 1. The values agree well with the previous data. It was not able to determine the $2 \mathrm{~V}$ because of the very thin fibrous nature of the minerals.

Optically, the Moroyose mesolite is very pure, while the Taira and the Motokohama mesolites contain scolecite of $10-20 \%$ in volume as an impurity. The close associations of scolecite with Japanese mesolites are rather common as has been described by Harada, Hara and Nakao (1968).

$\mathrm{X}$-ray powder data of the mesolites well correspond to the previous data. Applying the indices to $\mathrm{X}$-ray powder data given by Harada, Hara and Nakao (1968), the unit-cell edges for the mesolite from Moroyose were refined Silicon was used as an internal standard for the X-ray measurements.

The results are as follows: $a=56.7, b=6.53, c=18.44 \AA($ all $\pm 0.02 \hat{A})$ and $\beta=$ $90^{\circ}$. The calculated specific gravity of the Moroyose mineral applying these unit-cell dimensions and chemical analysis was 2.26. Unit-cell dimensions for the Taira and Motokohama minerals show no appreciable discrepancies from the Moroyose material.

\section{GHEMIGAL ANALYSES}

Each mesolite was analyzed chemically by the normal wet method. The results are also given in Table 1. Structural formulae, in which numbers of oxygen atoms are set to be 30 , are represented as follows:

Moroyose (pure material);

$$
\left(\mathrm{Na}_{1.07}, \mathrm{~K}_{0.01}, \mathrm{Ca}_{2.63}\right)_{3.61}\left(\mathrm{Al}_{6.17}, \mathrm{Fe}^{3+}{ }_{0.03}, \mathrm{Si}_{8.82}\right)_{15.02}, 0_{30} 8.16 \mathrm{H}_{2} \mathrm{O}
$$


Table 1. Chemical and physical properties of mesolites

\begin{tabular}{l|r|r|r}
\hline & \multicolumn{1}{|c|}{1} & \multicolumn{1}{c}{2} & \multicolumn{1}{c}{3} \\
\hline $\mathrm{SiO}_{2}$ & 45.42 & 43.56 & 38.32 \\
$\mathrm{Al}_{2} \mathrm{O}_{3}$ & 26.98 & 27.94 & 27.82 \\
$\mathrm{Fe}_{2} \mathrm{O}_{3}$ & 0.21 & 0.14 & 0.10 \\
$\mathrm{CaO}$ & 12.15 & 11.41 & 14.66 \\
$\mathrm{Na}_{2} \mathrm{O}$ & 2.84 & 3.55 & 3.09 \\
$\mathrm{~K}_{2} \mathrm{O}$ & 0.06 & 0.12 & 0.14 \\
$\mathrm{H}_{2} \mathrm{O}(+\&-)$ & 12.61 & 13.44 & 15.88 \\
$\mathrm{Total}$ & 100.27 & 100.16 & 100.01 \\
\hline \multicolumn{1}{c|}{$\mathrm{S}, \mathrm{G}}$. & 2.27 & 2.25 & 2.26 \\
\multicolumn{1}{c|}{$\alpha$} & 1.504 & 1.504 & 1.504 \\
\multicolumn{1}{c|}{$\gamma$} & 1.505 & 1.505 & 1.505 \\
$\gamma-\alpha$ & 0.001 & 0.001 & 0.001 \\
$c \wedge Y$ & $22^{\circ}-3^{\circ}$ & $3^{\circ}$ & $($ all \pm 0.001$)$ \\
\hline
\end{tabular}

Note, 1. Mesolite (pure material) from Moroyose (Analyst; K. Nagashima and $K$. Nakao).

2. Mesolite (containning about $10 \%$ in volume of scolecite) from Motokohama, Yaizu (Analyst; K. Nagashima and K. Nakao).

3. Mesolite (containning about 2096 in volume of scolecite and about $5 \%$ in volume of calcite) from Taira, Yaizu (Analyst; K. Nagashima and K. Nakao).

Refractive indices and specific gravity are determined by the immersion method at $20^{\circ} \mathrm{C}$ and pycnometer respectively.

Motokohama (after corrected for contaminating $10 \%$ in volume of scolecite);

$\left(\mathrm{Na}_{1.53}, \mathrm{~K}_{0.03}, \mathrm{Ca}_{2.33}\right)_{3.89}\left(\mathrm{Al}_{6.54}, \mathrm{Fe}^{3+}{ }_{0.02}, \mathrm{Si}_{8.52}\right)_{16.08} \mathrm{O}_{30} 8.81 \mathrm{H}_{2} \mathrm{O}$, and Taira (after corrected for contaminating $20 \%$ in volume of scolecite and about $5 \%$ in voeume of calcite):

$$
\left(\mathrm{Na}_{1.61}, \mathrm{~K}_{0.057}, \mathrm{Ca}_{2.46}\right)_{4.12}\left(\mathrm{Al}_{7.207}, \mathrm{Fe}_{0.02}, \mathrm{Si}_{7.90}\right)_{15.12} 0_{30} 9.50 \mathrm{H}_{2} \mathrm{O}
$$

These formulae agree well with the ideal formula for mesolite which shows $\mathrm{Si}+\mathrm{Al}=15$.

\section{IONIG SUBSTITUTIONS IN NATURAL MESOLITES}

Foster (1965) advocated the compositional range of mesolite as follows: $\mathrm{SiO}_{2}$ 44.4-47.1, $\mathrm{Al}_{2} \mathrm{O}_{3}$ 25.6-27.2, $\mathrm{CaO} 8.8-11.1, \mathrm{Na}_{2} \mathrm{O}$ 3.8-6.2 (all at by wt\%.). Harada, Hara and Nakao (1968) found a sodian mesolite with the composition of $\mathrm{SiO}_{2} 43.09 \mathrm{Al}_{2} \mathrm{O}_{3} 27.48, \mathrm{CaO} 7.48$ and $\mathrm{Na}_{2} \mathrm{O} 9.75$ (by wt. \%). In the present study, the authors confirmed a calcian mesolite from Moroyoes 
whose composition is as follows: $\mathrm{SiO}_{2} 45.42, \mathrm{Al}_{2} \mathrm{O}_{3} 26.98, \mathrm{CaO} 12.15$, and $\mathrm{Na}_{2} \mathrm{O}$ 2.84 (by wt. \%). Both the sodian mesolite as well as the calcian mesolite are very pure optically as well as X-ray spectrographically. Therefore, we can conclude the cationic substitution range in mesolite as follows: $\mathrm{CaO} 7.48-$ 12.15, $\mathrm{Na}_{2} \mathrm{O} 9.75-2.84$ (by wt. \%). The revised compositional ranges of the cations in natural mesolites are expressed as $\mathrm{Ca}=2.5-1.6, \mathrm{Na}=3.7-1.0$ when oxigen is set to be 30 . This wide compositional range of cations in mesolites can also be explained by large c.e.c. of the zeolite, $54.9 \mathrm{meq} / 100 \mathrm{gr}$ to 119.5 meq/ 100 gr found by Harada, Hara and Nakao (1968).

\section{ACKNOWLEDGEMENTS}

The authors wish to express their heartfelt thanks to Dr. Kazunosuke Masutomi of Japan Ass. Amateur Mineralogist, Kyoto and to Dr. Kameki Kinoshita, Prof. Emeritus of Kyushu University for offering the mesolite specimens. All specimens used in this study are deposited in the Sakurai Museum, National Science Museum and Chichibu Museum of Natural History.

Thanks are also due to Professor Toshio Sudo of Tokyo University of Education for leading this study.

\section{REFERENGES}

Foster, M.D. (1965), Studies of the zeolites: Composition of zeolites of natrolite group, U.S. Geol. Surv. Prof. Pap., 504-D, $1 \sim 7$.

Harada, K. (1968), Zeolite facies-with a note on its zonal distributions at various burial depths (in Japanese with English Abstract), Jour. Geol. Soc. Japan, 74, $239 \sim 244$.

-, Hara, M. and Nakao, K. (1968), Vineralogical notes on mesolite and scolecite from Japan, Mineral. Jour., (Tokyo), 5, 309 320.

Iijima, A. and Utada, M. (1966), Zeolites in sedimentary rocks, with reference to the depositional environments and zonal distribution, Sedimentology, 7, $327 \sim 357$.

Iijima, A. and Harada, K. (1969), Authigenic zeolites in zeolitic palagonite tuffs on Oahu, Hawaii, Am. Min. 54, (in press).

\section{天然産の中性沸石の同形イオン置換}

$$
\text { 原田一雄・中尾 和三・長島 弘三 }
$$

摘 要

日本の登武岩や安山岩の杏仁孔や細脈中に应出する中性沸石の，純度を吟味した精嘧な 重量法化学分炘の結果仙，Foster（1965）の示したよりはるかに広い陽イオンの同形た オン置換の湢持ち $\mathrm{Ca}=2.5-1.6, \mathrm{Na}=5.7-1.0 \quad(0=30)$ であったこの事实は， Harada, Hara and Nakao (1968) により示された，中性沸石が比較的大きな陽イオン 交換容量を持っている事实からも補足支持することができる。 